\title{
RAISING PRODUCTIVITY AND QUALITY OF SUGAR BEET USING OF SEED INOCULATION AND FOLIAR APPLICATION WITH AZOSPIRILLUM BRASILIENSE AND BACILLUS MEGATHERIUM. Sahar H. Rashed*; Ranya M.Abdel Aziz**; Sahar M.I. Moustafa** and Shahrzad M.M. Neana** *Soil, Water and Environment Res.Inst.,Agric.Res. Center,Giza,Egypt ** Sugar Crops Res. Inst., Agric. Res. Center, Giza, Egypt
}

\begin{abstract}
Two field experiments were conducted in 2012-2013 and 2013-2014 seasons in Nubaria, Alexandria Governorate to study the effect of seed inoculation and foliar application with Azospirillum and/or Bacillus on growth, yield and quality of sugar beet fertilized with $\mathrm{N}(90 \mathrm{~kg} \mathrm{~N} / \mathrm{fed})$ and $\mathrm{P}\left(30 \mathrm{~kg} \mathrm{P} \mathrm{O}_{5} / \mathrm{fed}\right.$.). The experiments included 10 treatments with three replicates arranged in a randomized complete block design. Application of both biofertilizers either alone or in combination led to a significant improvement in most sugar beet traits as compared with control (untreated with biofertilizers).

Meantime, the response differed according to the kind of biofertilizers. The highest stimulatory effects were exerted in plants treated with the mixture of Azospirillum and Bacillus than either of them alone.

This treatment significantly improved growth parameters (root length, root diameter and root fresh weight), root quality (Total Soluble Solids \% and sucrose \%), nitrogen, phosphorus and potassium contents and increased tops, roots and sugar yields in both seasons.

Azospirillum was more effective than Bacillus on growth parameters, root nitrogen and potassium \%, tops, roots and sugar yield. But Bacillus was more effective on sucrose \% and $\mathrm{P} \%$ only.

Seed inoculation along with foliar application was the best method on most traits under study.

The interactions between biofertilizers and their methods of application led to significant increases in root diameter in the two seasons, root fresh weight, nitrogen, phosphorus and potassium content in the first season, tops yield in the two seasons and root yield in the second season. Therefore, using seed inoculation along with foliar application of the mixture of Azospirillum and Bacillus was the best interaction treatment, which gave the best results and is recommended for beet cultivation in order to minimize soil and water pollution adverse effects.

The interaction between both studied factors had a significant effect on all studied characters in the two growing seasons.

Generally, since sugar beet showed in previous studies response to addition reaching go to $90 \mathrm{~kg} \mathrm{~N} / \mathrm{fed}$ and attains reaching $30 \mathrm{~kg} \mathrm{P}_{2} \mathrm{O}_{5} / \mathrm{fed}$, the use of the two biofertilizers under study might have had complemented the $\mathrm{N}$ and $\mathrm{P}$ requirements where only $90 \mathrm{~kg} \mathrm{~N} /$ fed and $30 \mathrm{~kg} \mathrm{P}_{2} \mathrm{O}_{5} /$ fed were added.
\end{abstract}

Keywords:Sugar beet,seed inoculation,foliar application,azospirillum barasiliense,Bacillus megatherium

\section{INTRODUCTION}

There are several advantages favoring sugar beet as a suitable crop to increasing sugar production in Egypt. The crop is growing annually during the winter season, with a relatively short duration period and allows for growing a summer crop during the same year. In recent years, biofertilizers have emerged as a promising component of integrating nutrient supply system in intensive agriculture. Sprenat, (1990) recorded that inoculation soil by Azotobacter spp caused solubilization of mineral nutrients and synthesis of vitamins, amino acids, auxins as well as gibberellins, which stimulate plant growth and induce high yields. EL-Badry and EL-Bassel, (1993) and Favilli et al., (1993) found that inoculation sugar beet with Azospirillum caused a significant saving in nitrogen fertilizer (about 25-40 \%). They also reported that a significant increase in root yield (from 2.8 to 6.0 t/fed.) and sugar yield as a result of inoculation by Azospirillum.

Azospirillum proved to be more efficient and effective as far as growth and hence root and sugar yields per fadden whereas Bacillus was more effective regarding sucrose content. Both bacteria were either used as seed soaking and /or sprayed two months after sowing. Seed soaking was more effective than foliar application of the two biofertilizers. This effectiveness clearly indicates that seed soaking might have had enhanced early growth of sugar beet plants, probably due to hormones effect (Fisinin et al., 1999).

In recent years, the trend is to explore the possibility of supplementing chemical fertilizers with more particularly biofertilizers of microbial origin at the same time minimizing the environmental pollution which resulted from mineral fertilizers and also to reduce its coasts (Abu EL-Fotoh et al., 2000 and Cakmakci et al., 2001). Many studies with this respect were done i.e.

Sultan et al., (1999) and Bassal et al., (2001) recorded that inoculation of sugar beet seeds with Azotobacterin significantly increased TSS \%, sucrose $\%$, purity $\%$ and root as well as sugar yields/fed. . Cakmakci et al., (2001) and Maareg and Badr, (2001) reported that Syrialin caused an increase TSS \%, sucrose $\%$, purity $\%$ and sugar yield/fed. Kandil et al., (2002) confirmed that biofertilization treatments significantly increased root, top and sugar yields/fed. The highest means of previously mentioned characteristics were resulted from inoculation seeds of sugar beet with Rhizobacterin. Ramadan et al., (2003) showed that biofertilization treatments had a significant effect on root, top and sugar yields/fed. On the other hand, biofertilization treatments exhibited insignificant effect in sucrose \% and purity \%. Badawi et al., (2004) found that biofertilization treatments caused a significant effect on TSS $\%$, sucrose $\%$, purity $\%$, root, top and sugar yields/fed. Rhizobacterin treatment 
produced the highest values of yield quality parameters, excluding TSS \% (in the first and third seasons) and purity \% (in the second season) as well as all yield characters in both seasons. Concerning application of the mixture of Rhizobacterin + Cerialine and Cerialine biofertilizer, its ranked after Rhizobacterin treatment, respectively with respecting their effect on quality and yield traits in both seasons. While, control treatment resulted in the lowest means ones.

Therefore, attempts have been paid to the use biofertilizers as being most cheap and safe for agricultural application. They are extremely beneficial in enriching fertility soil with those micro-organisms, which fix atmospheric $\mathrm{N}$ and make plant nutrient more available.

Bacillus $\mathrm{sp}$ is one of the biofertilizers which could supply plants with their needs from phosphorus during their growth and as well improve soil structure and increase fertility. Abou Zeid and Osman, (2005), Aly et al., (2008), Soudi et al., (2008). found that these bacteria significantly increased root length, root diameter, root and tops fresh weight as well as sucrose, TSS, and purity percentages and yields of tops, roots and sugar. Aly et al., (2009) recorded that inoculation with Azotobacter chroococcum and Bacillus megatherium saved about $25 \mathrm{~kg} \mathrm{~N} / \mathrm{fed}$. of mineral fertilizer, which reduced the cost of production and the environmental pollution, in addition to the increase of sugar yield and recoverable sugar/fed.

Furthermore, inoculation with Azospirillum increased sucrose content in sugar beet roots. Also, Seadh, (2008), Shewate et al., (2008), Zhang et al., (2009), El-Sarag, (2009) and Attia et al., (2011) found that bacterial inoculation of sugar beet seeds though caused insignificant increases in root quality and growth parameters but it significantly increased root and sugar yields/fed. Bacillus inoculation along with $40 \mathrm{~kg} \mathrm{~N} / \mathrm{fed}$. gave root and sugar yields as those obtained by addition of $80 \mathrm{~kg} \mathrm{~N} / \mathrm{fed}$. Furthermore, Bacillus inoculation along with the addition of the full $\mathrm{N}$ dose $80 \mathrm{~kg} / \mathrm{fed}$. gave a significant increase which amounted to 18 and $39 \%$ in root and sugar yields, respectively compared to application of $80 \mathrm{~kg} / \mathrm{fed}$. alone.

Abd EL- daiem and Tawfic, (2015). Reported thatApplication the mixture of Microbeen + Rhizobacterin+ Phosphorien produced the highest values of all studied characters of suger beet in both growing seasons as compared with using each biofertilizer alone. It was followed by application the mixture of Microbeen + Rhizobacterin then application the mixture of Rhizobacterin + Phosphorien in the two growing seasons. Generally, it could be concluded that application of the mixture of Microbeen + Rhizobacterin + Phosphorien as biofertilizers and adding $105 \mathrm{~kg} \mathrm{~N} / \mathrm{fed}$. as a mineral fertilization for maximizing sugar beet productivity under the environmental conditions of El-Qureen Village Sharkia Governorate.

The aim of the present investigation is to determine the effect of the use of two biofertilizers and their mode of application on the growth, quality and yield of sugar beet.

\section{MATERIALS AND METHODS}

Two field experiments were carried out at the Experimental Farm of Nubaria, Alexandria Governorate during 2012/2013and 2013/2014 seasons to study the effect of seed inoculation and foliar application with Azospirillum brasiliense and/or Bacillus megatherium on growth, yield and quality of sugar beet. The soil mechanical and chemical properties of the experimental sites were determined according to Jackson, (1973) and are shown in Table (1).

Table 1. Some physical and chemical analysis of the experimental site.

\begin{tabular}{|c|c|c|c|c|c|c|c|c|c|c|c|c|}
\hline \multirow[b]{2}{*}{ Seasons } & \multicolumn{3}{|c|}{ Partial size \% } & \multirow{2}{*}{\begin{tabular}{|c|} 
Soil \\
Textural \% \\
\end{tabular}} & \multirow{2}{*}{$\begin{array}{c}\text { Soil pH } S \\
1: 2.5\end{array}$} & \multirow{2}{*}{$\begin{array}{l}\text { E.C*. } \\
\text { dsm-1 }\end{array}$} & \multirow{2}{*}{$\begin{array}{c}\mathrm{CaCO3} \\
\% \\
\end{array}$} & \multirow{2}{*}{$\begin{array}{c}\text { O.M } \\
\%\end{array}$} & \multicolumn{4}{|c|}{ Available contents mgkg-1 } \\
\hline & Clay & Silt & Sand & & & & & & $\mathbf{N}$ & $\mathbf{F}$ & & $\mathbf{K}$ \\
\hline $2012 / 2013$ & 3.0 & 3.3 & 93.7 & Sandy & 7.7 & 1.61 & $10.6 \%$ & 0.75 & 4.4 & 3.2 & & 132 \\
\hline 2014 & 3.6 & 4.7 & 91.7 & Sandy & 7.8 & 1.62 & $9.9 \%$ & 0.90 & 6.5 & 3. & & 120 \\
\hline \multirow{2}{*}{ Seasons } & \multicolumn{4}{|c|}{ Soluble cations (meq/l) } & \multicolumn{4}{|c|}{ Soluble anions (meq/l) } & \multicolumn{4}{|c|}{ Available contents (mgkg-1) } \\
\hline & $\mathrm{Ca}++$ & $\mathrm{Mg}++$ & $\mathrm{Na}+$ & $\mathrm{K}+$ & CO3- & HCO3- & $\mathrm{Cl}-$ & SO4- & $\mathrm{B}$ & $\mathrm{Fe}$ & $\mathrm{Zn}$ & $\mathrm{Mn}$ \\
\hline $2012 / 2013$ & 2.00 & 3.02 & 3.24 & 0.25 & 0.00 & 1.84 & 3.76 & 2.91 & 0.31 & 4.2 & 2.6 & 3.8 \\
\hline $2013 / 2014$ & 2.05 & 3.00 & 3.14 & 0.35 & 0.00 & 1.87 & 3.78 & 2.88 & 0.35 & 4.1 & 3.5 & 2.4 \\
\hline
\end{tabular}

*In the soil paste extract.

Azospirillum brasiliense and Bacillus megatherium microbes were isolated from sugar beet fields and then were identified and preserved by the Pathology Lab., Unit, Agriculture Research Center (ARC), Giza, Egypt. Preparation of bacteria was made according to Hino and Wilson, (1959).

Seeds of a multigerm sugar beet variety (Lola) were planted on $10^{\text {th }}$ and $15^{\text {st }}$ of October in 2012 and 2013, respectively. Seeds were inoculated with Azospirillum brasiliense and/or Bacillus megatherium by over night socking in a large basin containing the bacterial suspension. Foliar application of these bacteria was made after 50 days from sowing. The concentrations of Azospirillum brasiliense and Bacillus megatherium were $\left(10^{9}\right.$ cells $\left./ \mathrm{ml}\right)$ and $\left(10^{5}\right.$ cells $\left./ \mathrm{L}\right)$ for seed inoculation and foliar application, respectively.

The experiments included 10 treatments with three replicates arranged in a randomized complete block design.

The plot area was $21 \mathrm{~m}^{2}$ (5 rows, $60 \mathrm{~cm}$ apart and $7 \mathrm{~m}$ long). The distance between hills was $20 \mathrm{~cm}$. The treatments were as follows:

1-Control (without biofertilization).

2-Inoculation of seeds with Azospirillum.

3-Inoculation of seeds with Bacillus. 
4- Inoculation of seeds with a mixture of Azospirillum and Bacillus.

5- Foliar application of Azospirillum

6- Foliar application of Bacillus.

7- Foliar application of a mixture of Azospirillum and Bacillus.

8- Inoculation and foliar application of Azospirillum

9- Inoculation and foliar application of Bacillus.

10- Inoculation and foliar application of a mixture of Azospirillum and Bacillus.

Mineral nitrogen fertilizer was applied at a level of $90 \mathrm{~kg} \mathrm{~N} / \mathrm{fed}$ as in the form of ammonium nitrate $(33.5 \% \mathrm{~N})$ in two equal doses applied after thinning (45 days from sowing) and the second was applied one month later. Phosphorus fertilizer was applied as ordinary super phosphate at a level $30 \mathrm{~kg} \mathrm{P}_{2} \mathrm{O}_{5} / \mathrm{fed}$ during seedbed preparation. Potassium fertilizer was applied at a level of $24 \mathrm{~kg} \mathrm{~K}_{2} \mathrm{O} / \mathrm{fed}$ potassium sulfate $48 \% \mathrm{~K}_{2} \mathrm{O}$ with the second dose of $\mathrm{N}$ fertilizer. All cultural practices for growing sugar beet were done as recommended.

Random samples were taken from each plot at harvest (7 month from sowing) to determine:

Growth parameters:

1. Root length $(\mathrm{cm})$.

2. Root diameter $(\mathrm{cm})$.

3. Root fresh weight ( $\mathrm{Kg} / \mathrm{plant})$.

II. Root quality

1. Total Soluble Solids (TSS \%) was determined using

Handle Refractometer.
2. Sucrose \% was determined using Saccharometer apparatus according to the procedure outlined by Le Doct, (1927).

3. Purity $\%=$ Sucrose $\%$ x $100 /$ TSS $\%$.

\section{Nutrient contents of roots:}

$\mathrm{N}, \mathrm{P}$ and $\mathrm{K} \%$ in roots were determined according to A.O.A.C. (1990).

\section{Yield and yield components.}

To determine yield and its components, the four rows of each plot were harvested, topped and weighed to determine:

1. Top yield (ton/fed.).

2. Root yield (ton/fed.).

3.Sugar yield (ton/fed.).Calculated by multiply root yield x sucrose $\%$.

Analysis of variance was carried out according to Steal and Torrie, (1980), and the treatment means were compared using L.S.D. at $5 \%$ level of significantly.

\section{RESULTS AND DISCUSSION}

\section{I- Growth parameters:}

Biofertilization treatments caused a significant effect on root length, root diameter and root fresh weight as affected by seed inoculation and foliar application separately and together with Azospirillum and Bacillus either alone or in combination are presented in Table (2).

All yields attributes that in root length, root diameter and root fresh weight were significantly increased in the two seasons due to bacterial treatments compared with the control (untreated with bacteria).

Table (2): Effect of seed inoculation and foliar application with Azospirillum and Bacillus on some growth criteria of sugar beet plants in the two seasons.

\begin{tabular}{|c|c|c|c|c|c|c|}
\hline \multirow{2}{*}{ Treatments } & \multicolumn{2}{|c|}{ Root length (cm) } & \multicolumn{2}{|c|}{ Root diameter (cm) } & \multicolumn{2}{|c|}{ Root fresh weight (Kg/ plant)) } \\
\hline & $2012 / 2013$ & $2013 / 2014$ & $2012 / 2013$ & $2013 / 2014$ & $2012 / 2013$ & $2013 / 2014$ \\
\hline Control (without biofertilizers) & 22.5 & 22.65 & 10.50 & 10.65 & 0.85 & 0.90 \\
\hline Azospirillum (In)* & 24.85 & 24.95 & 10.85 & 10.95 & 1.05 & 1.15 \\
\hline Bacillus (In) & 24.25 & 24.39 & 10.70 & 10.80 & 1.00 & 1.07 \\
\hline Azospirillum+Bacillus(In) & 25.10 & 25.30 & 11.10 & 11.25 & 1.20 & 1.28 \\
\hline Mean & 24.17 & 24.32 & 10.79 & 10.91 & 1.02 & 1.10 \\
\hline Azospirillum $(\mathrm{F}) * *$ & 25.00 & 25.15 & 11.00 & 11.15 & 1.15 & 1.25 \\
\hline Bacillus (F) & 24.64 & 24.80 & 10.90 & 11.05 & 1.05 & 1.17 \\
\hline Azospirillum+Bacillus (F) & 25.20 & 25.30 & 11.35 & 11.55 & 1.35 & 1.48 \\
\hline Mean & 24.95 & 25.08 & 11.08 & 11.25 & 1.18 & 1.30 \\
\hline Azospirillum (In + F ) & 25.20 & 25.35 & 11.15 & 11.25 & 1.28 & 1.35 \\
\hline Bacillus (In + F ) & 24.90 & 25.00 & 11.05 & 11.15 & 1.17 & 1.25 \\
\hline Azospirillum+Bacillus (In +F) & 25.45 & 25.60 & 11.65 & 11.85 & 1.44 & 1.56 \\
\hline Mean & 25.18 & 25.32 & 11.28 & 11.42 & 1.30 & 1.39 \\
\hline $\begin{array}{l}\text { Mean of Azospirillum } \\
\text { Bacillus } \\
\text { Azospirillum+Bacillus }\end{array}$ & $\begin{array}{l}25.02 \\
24.60 \\
25.25\end{array}$ & $\begin{array}{c}25.15 \\
24.73 \\
25.4\end{array}$ & $\begin{array}{l}11.00 \\
10.88 \\
11.37\end{array}$ & $\begin{array}{l}11.12 \\
11.00 \\
11.55\end{array}$ & $\begin{array}{l}1.16 \\
1.07 \\
1.33\end{array}$ & $\begin{array}{l}1.25 \\
1.19 \\
1.34\end{array}$ \\
\hline $\begin{array}{l}\text { LSD at } 5 \% \text { Bacteria (B) } \\
\text { Methods }(M) \quad(B) \times(M)\end{array}$ & $\begin{array}{l}0.87 \\
1.02 \\
\text { N.S }\end{array}$ & $\begin{array}{l}0.84 \\
1.01 \\
\text { N.S }\end{array}$ & $\begin{array}{l}0.24 \\
\text { N.S } \\
0.46\end{array}$ & $\begin{array}{l}0.14 \\
0.16 \\
0.30\end{array}$ & $\begin{array}{l}0.01 \\
\text { N.S } \\
0.03\end{array}$ & $\begin{array}{l}0.04 \\
\text { N.S } \\
\text { N.S }\end{array}$ \\
\hline
\end{tabular}

$(\text { In) })^{*}=$ Inoculation of seeds $(\mathbf{F})^{* *}=$ Foliar application

The highest stimulatory effect and the maximum enhancement were exerted in plants treated with the combination of Azospirillum and Bacillus than with either of them alone. With all, the treatment with Azospirillum exhibited more pronounced and significant effect than Bacillus.
The available data regarding to bacteria application methods, there were significant differences between methods for root length only in both seasons. Inoculation of seeds exhibited significant increase over foliar application. Moreover, seeds inoculation and foliar application together gave better results than seeds inoculation alone but this increase was not significant. 
The interactions between biofertilizers and their application methods were significant for root diameter in the two seasons and root fresh weight in the first season.

Seed inoculation along with foliar spray gave the best results than other treatments under study followed by seed inoculation with the mixture of Azospirillum and Bacillus. The stimulatory effects of both used biofertilizers on the growth might be attributed to the activation of the growth of microflora including many plant growth stimulators (Fisinin et al., 1999).

Also, Aly, (2003) found that, Azospirillum and Bacillus are capable to produce some of hormones such as IAA, IBA, GA and ABA and making the other nutrients more available. This in turn induces the proliferation of roots and root hairs and hence may increase nutrient absorbing surfaces and therefore enhance the growth. These results are in agreement with those obtained by El-Sayed, (1998), Sukhovitskaya, (1998),Abou Zeid and Osman, (2005) , Elkoca et al., (2008), Abd EL-daiem et al., (2015 $a$ and b) and Abd EL-Daiem and Tawfic (2015).

\section{II- Root quality}

The available data root quality comprises several parameters i.e. total soluble solids, sucrose content and juice purity $\%$ and are presented in Table (3).
The results indicated that, Azospirillum and Bacillus individually or in combination significantly increased total soluble solids $\%$ and sucrose $\%$ in two seasons and purity in first season as compared with control.

Also, the available data cleared that Bacillus treatment was more effective on root quality than Azospirillum but these effects did not reach the level of significance for total soluble solids $\%$ and purity.

On the other hand, the combination of Azospirillum and Bacillus significantly increased total soluble solids \% and sucrose $\%$ in both seasons and purity $\%$ in the first season as compared with Azospirillum or Bacillus alone.

Regarding the methods of bacteria application, data showed that these methods insignificantly affected root quality in both seasons except sucrose \% in the second season. In general, seed inoculation along with foliar application was the best method gave the highest sucrose $\%$.

As for, the interactions between bacteria and their application methods, on root quality were insignificant as shown in Table, (3). These results are in harmony with those found by Awad,(2000), Soudi et al., (2008), Aly et al., (2008) and Abd EL- daiem and Tawfic, (2015).

Table (3). Effect of seed inoculation and foliar application with Azospirillum and Bacillus on root quality of sugar beet plants in the two seasons.

\begin{tabular}{|l|c|c|c|c|c|c|}
\hline \multirow{2}{*}{ Treatments } & \multicolumn{2}{|c|}{ Total Soluble Solids \% } & \multicolumn{2}{c|}{ Sucrose \% } & \multicolumn{2}{c|}{ Purity \% } \\
\cline { 2 - 7 } & $\mathbf{2 0 1 2 / 2 0 1 3}$ & $\mathbf{2 0 1 3 / 2 0 1 4}$ & $\mathbf{2 0 1 2 / 2 0 1 3}$ & $\mathbf{2 0 1 3 / 2 0 1 4}$ & $\mathbf{2 0 1 2 / 2 0 1 3}$ & $\mathbf{2 0 1 3 / 2 0 1 4}$ \\
\hline Control (without biofertilizers) & 20.12 & 20.25 & 16.00 & 16.05 & 79.52 & 79.26 \\
\hline Azospirillum (In)* & 21.17 & 21.35 & 16.35 & 16.45 & 77.23 & 77.05 \\
\hline Bacillus (In) & 20.85 & 20.95 & 16.65 & 16.75 & 79.86 & 79.95 \\
\hline Azospirillum+Bacillus(In) & 21.35 & 21.50 & 17.10 & 16.25 & 80.10 & 75.58 \\
\hline Mean & 20.87 & 21.01 & 16.52 & 16.62 & 79.16 & 79.10 \\
\hline Azospirillum (F)** & 21.25 & 21.30 & 16.25 & 16.40 & 76.47 & 76.99 \\
\hline Bacillus (F) & 21.05 & 21.15 & 16.45 & 16.60 & 78.15 & 78.49 \\
\hline Azospirillum+Bacillus (F) & 21.64 & 21.75 & 16.95 & 17.10 & 78.33 & 78.62 \\
\hline Mean & 21.31 & 21.40 & 16.55 & 16.70 & 77.66 & 78.04 \\
\hline Azospirillum (In+F) & 21.20 & 21.25 & 16.35 & 16.42 & 77.12 & 77.27 \\
\hline Bacillus (In + F) & 21.00 & 21.05 & 16.55 & 16.70 & 78.81 & 79.33 \\
\hline Azospirillum+Bacillus (In +F) & 21.30 & 21.40 & 16.75 & 16.91 & 78.64 & 79.02 \\
\hline Mean & 21.17 & 21.23 & 16.55 & 16.67 & 78.18 & 78.52 \\
\hline Mean of Azospirillum & 21.21 & 21.30 & 16.32 & 16.42 & 76.94 & 77.09 \\
Bacillus & 20.97 & 21.05 & 16.55 & 16.68 & 78.92 & 79.24 \\
Azospirillum+Bacillus & 21.43 & 21.55 & 16.93 & 16.75 & 79.00 & 77.73 \\
\hline LSD at 5\% Bacteria (B) & 0.32 & 0.57 & 0.24 & 0.20 & 1.80 & N.S \\
Methods (M) & N.S & N.S & N.S & 0.19 & N.S & N.S \\
(B) x (M) & N.S & N.S & N.S & N.S & N.S & N.S \\
\hline
\end{tabular}

$\left(\right.$ In) $*=$ Inoculation of seeds $\quad(\mathbf{F})^{* *=\text { Foliar application }}$

\section{Root nutrient contents:}

The available data in Table (4) showed a significant increase in root $\mathrm{N}, \mathrm{P}$ and $\mathrm{K}$ contents in the two seasons in response to the application of Azospirillum and Bacillus separately or in combination compared to control.

The beneficial effect of Azospirillum bacteria was reflected on the improvement of $\mathrm{N} \%$ and $\mathrm{K} \%$, while Bacillus was for $\mathrm{P} \%$. It is worth to mention that the highest stimulatory effects were exerted in plants treated with the mixture of Azospirillum and Bacillus.

As for the methods of bacterial addition, data Table (4) indicated significant differences among those methods, where, seed inoculation and foliar spray together was the best method which gave the highest root $\mathrm{N}, \mathrm{P}$ and $\mathrm{K}$ content. 
Table (4). Effect of seed inoculation and foliar application with Azospirillum and Bacillus on N, P and $\mathrm{K} \%$ of roots of sugar beet plants in the two seasons.

\begin{tabular}{|l|c|c|c|c|c|c|}
\hline \multirow{2}{*}{ Treatments } & \multicolumn{2}{|c|}{ Nitrogen \% } & \multicolumn{2}{c|}{ Phosphor \% } & \multicolumn{2}{c|}{ Potassium \% } \\
\cline { 2 - 7 } & $\mathbf{2 0 1 2 / 2 0 1 3}$ & $\mathbf{2 0 1 3 / 2 0 1 4}$ & $\mathbf{2 0 1 2 / 2 0 1 3}$ & $\mathbf{2 0 1 3 / 2 0 1 4}$ & $\mathbf{2 0 1 2 / 2 0 1 3}$ & $\mathbf{2 0 1 3 / 2 0 1 4}$ \\
\hline Control (without biofertilizers) & 1.39 & 1.42 & 0.36 & 0.35 & 1.02 & 1.03 \\
\hline Azospirillum (In)* & 1.46 & 1.49 & 0.39 & 0.39 & 1.00 & 1.08 \\
\hline Bacillus (In) & 1.40 & 1.47 & 0.47 & 0.41 & 0.98 & 1.07 \\
\hline Azospirillum+Bacillus (In) & 1.63 & 1.51 & 0.43 & 0.50 & 1.13 & 1.16 \\
\hline Mean & 1.50 & 1.49 & 0.43 & 0.43 & 1.04 & 1.10 \\
\hline Azospirillum (F)** & 1.49 & 1.52 & 0.38 & 0.39 & 1.07 & 1.13 \\
\hline Bacillus (F) & 1.46 & 1.50 & 0.44 & 0.42 & 0.98 & 1.07 \\
\hline Azospirillum+Bacillus (F) & 1.64 & 1.55 & 0.49 & 0.57 & 1.14 & 1.19 \\
\hline Mean & 1.53 & 1.52 & 0.44 & 0.46 & 1.06 & 1.13 \\
\hline Azospirillum (In+F) & 1.62 & 1.53 & 0.38 & 0.43 & 1.13 & 1.16 \\
\hline Bacillus (In + F) & 1.55 & 1.48 & 0.49 & 0.47 & 1.08 & 1.09 \\
\hline Azospirillum+Bacillus (In +F) & 1.70 & 1.63 & 0.55 & 0.59 & 1.21 & 1.23 \\
\hline Mean & 1.62 & 1.55 & 0.47 & 0.50 & 1.14 & 1.16 \\
\hline Mean of Azospirillum & 1.52 & 1.51 & 0.38 & 0.40 & 1.07 & 1.12 \\
Bacillus & 1.47 & 1.48 & 0.47 & 0.43 & 1.01 & 1.08 \\
Azospirillum+Bacillus & 1.66 & 1.56 & 0.49 & 0.55 & 1.16 & 1.19 \\
\hline LSD at 5\% & & & & & & \\
Bacteria (B) & 0.05 & 0.03 & 0.02 & 0.03 & 0.03 & 0.02 \\
Methods (M) & 0.05 & 0.04 & 0.03 & 0.04 & 0.03 & 0.02 \\
(B) x (M) & 0.09 & N.S & 0.04 & N.S & 0.05 & N.S \\
\hline
\end{tabular}

$(\text { In })^{*}=$ Inoculation of seeds $\quad(\mathbf{F})^{* *}=$ Foliar application

In respect of the interactions between the kind of bacteria and their application methods, data illustrated a significant increase in $\mathrm{N}, \mathrm{P}$ and $\mathrm{K} \%$ in the first season only. The best interaction which exhibited the highest values was for seed inoculation along with foliar spray with the mixture of both bacteria.

Where as, the lowest values of $\mathrm{N}$ and $\mathrm{K} \%$ were obtained by inoculation with Bacillus alone and that of P\% by foliar spray with Azospirillum.

The favorable effect of biofertilizers treatments on $\mathrm{N}, \mathrm{P}$ and $\mathrm{K} \%$ may be refereed to their influence on increasing the availability of such nutrients and increased plant growth which enhance the absorption of nutrients from soil and then the synthesis, assimilation and translocation to roots. These results are in agreement with those obtained by Shehata and ElKhamwas, (2003), Soudi et al., (2008), Awad et al,(2012), Awad et al., (2013 a,b and c) and Abd ELdaiem and Tawfic, (2015).

IV- Tops, roots and sugar yields:

The results in Table (5) showed that top, root and sugar yields were significantly increased due to the application of each of Azospirillum and Bacillus either separately or in combination in two seasons compared with control.

Table (5). Effect of seed inoculation and foliar application with Azospirillum and Bacillus on tops, roots and sugar yields of sugar beet plants in the two seasons.

\begin{tabular}{|l|c|c|c|c|c|c|}
\hline \multirow{2}{*}{ Treatments } & \multicolumn{2}{c|}{ Tops yield (ton/fed) } & \multicolumn{2}{c|}{ Roots yield (ton/fed) } & \multicolumn{2}{c|}{ Sugar yield (ton/fed) } \\
\cline { 2 - 7 } & $\mathbf{2 0 1 2 / 2 0 1 3}$ & $\mathbf{2 0 1 3 / 2 0 1 4}$ & $\mathbf{2 0 1 2 / 2 0 1 3}$ & $\mathbf{2 0 1 3 / 2 0 1 4}$ & $\mathbf{2 0 1 2 / 2 0 1 3}$ & $\mathbf{2 0 1 3 / 2 0 1 4}$ \\
\hline Control (without biofertilizers) & 10.10 & 10.30 & 27.50 & 27.85 & 4.40 & 4.47 \\
\hline Azospirillum (In)* & 12.25 & 12.35 & 28.32 & 28.55 & 4.63 & 4.70 \\
\hline Bacillus (In) & 12.05 & 12.15 & 26.84 & 27.15 & 4.47 & 4.55 \\
\hline Azospirillum+Bacillus(In) & 12.45 & 12.60 & 28.65 & 29.05 & 4.90 & 5.01 \\
\hline Mean & 11.71 & 11.85 & 27.83 & 28.15 & 4.60 & 4.68 \\
\hline Azospirillum (F)** & 12.10 & 12.15 & 28.05 & 28.15 & 4.63 & 4.62 \\
\hline Bacillus (F) & 12.00 & 12.08 & 26.50 & 26.70 & 4.36 & 4.43 \\
\hline Azospirillum+Bacillus (F) & 12.35 & 12.50 & 28.33 & 28.85 & 4.80 & 4.93 \\
\hline Mean & 12.15 & 12.24 & 27.63 & 27.90 & 4.57 & 4.66 \\
\hline Azospirillum (In+F) & 11.95 & 12.10 & 28.30 & 28.50 & 4.63 & 4.68 \\
\hline Bacillus (In + F) & 11.80 & 11.95 & 27.85 & 28.10 & 4.61 & 4.69 \\
\hline Azospirillum+Bacillus (In +F) & 12.15 & 12.35 & 28.65 & 28.95 & 4.80 & 4.89 \\
\hline Mean & 11.97 & 12.13 & 28.27 & 28.52 & 4.68 & 4.75 \\
\hline Mean of Azospirillum & 12.10 & 12.20 & 28.22 & 28.40 & 4.63 & 4.67 \\
Bacillus & 11.95 & 12.06 & 27.06 & 27.32 & 4.48 & 4.56 \\
Azospirillum+Bacillus & 12.32 & 12.48 & 28.54 & 28.95 & 4.83 & 4.94 \\
\hline LSD at 5\% & & & & & & \\
Bacteria (B) & 0.24 & 0.12 & 0.27 & 0.22 & 0.08 & 0.09 \\
Methods (M) & 0.21 & 0.11 & 0.24 & 0.19 & 0.07 & 0.07 \\
(B) x (M) & 0.42 & 0.23 & N.S & 0.38 & N.S & N.S \\
\hline
\end{tabular}

$(\mathbf{I n})^{*}=$ Inoculation of seeds $\quad(\mathbf{F})^{* *}=$ Foliar application 
Also, the available data showed that, in general, application of the mixture of Azospirillum with Bacillus followed by Azospirillum alone were significantly more effective than Bacillus alone in both seasons.

Dealing with the methods of bacterial addition, the results indicated that inoculation of seeds and foliar spray together increased significantly top, root and sugar yields than either of them alone (Table 5). From these results, it is worth to mention that the interactions between biofertilizers and their addition methods exerted a significant increase for top yield in the two seasons and root yield in the second season only.

In general, the application of both seed inoculation along with foliar application with the mixture of Azospirillum and Bacillus was the best treatment, which recorded the highest yield values.

The beneficial effects of bacteria might be attributed to the enhancement of root growth parameter particularly root weight (Ghosh and Mohiuddin, 2000). These results are in agreement with those obtained Zodape, (2001) and Abd EL-daiem et al., (2015 a and b) concluded that, the increase in yield productivity with biofertilizers application was partly due to microelement and plant growth regulators contained in this fertilizer. The same trend was also recorded by Shehata and El-Khamwas ,(2003), Maareg et al., (2005) and Abd EL-daiem and Tawfic, (2015).

\section{CONCLUSION}

The present results clearly indicate the possibility of the use of biofertilization in complementing the need of sugar beet to nitrogen and phosphorus.

Azospirillum was served to enhance atmospheric $\mathrm{N}$ fixation whereas Bacillus was served to solubilize soil phosphorus. Azospirillum proved to be more efficient and effective as far as growth and hence root and sugar yields per fed. whereas Bacillus was more effective regarding sucrose content. Both bacteria were either used as seed soaking and /or sprayed two months after sowing. Seed soaking was more effective than foliar application of the two biofertilizers. This effectiveness clearly indicates that seed soaking might have had enhanced early growth of sugar beet plants, probably due to hormones effect (Fisinin et al., 1999).

Generally, since sugar beet showed in previous studies response to addition reaching go to $140 \mathrm{~kg} \mathrm{~N} / \mathrm{fed}$ and attains reaching $45 \mathrm{~kg} \mathrm{P}_{2} \mathrm{O}_{5} / \mathrm{fed}$, the use of the two biofertilizers under study might have had complemented the $\mathrm{N}$ and $\mathrm{P}$ requirements where only $90 \mathrm{~kg} \mathrm{~N} / \mathrm{fed}$ and $30 \mathrm{~kg} \mathrm{P}_{2} \mathrm{O}_{5}$ /fed were added.

\section{REFERENCES}

A.O.A.C. (1990). "Official Methods of Analysis Association of Official Analysis Chemist". 15th Ed Washington U.S.A.

Abd EL- Daiem, Kh.M and S.F. Tawfic (2015).Response of sugar beet plant (Beta vulgaris L.) to mineral nitrogen fertilization and biofertilizers,Int.J.Curr.Microbiol.App.Sci.,4(9):6 $77-688$.
Abd EL- Daiem, Kh.M;Sh.A. Tantaey and Sh.M.M. Neana $\left(2015^{\mathrm{a}}\right)$.Effect of foliar application of microelements and potassium levels on growth, physiological and quality characters of sugar beet (Beta vulgaris L.) under newly reclaimed soils. J. Agric. Sci., Mansoura Univ, 6 (1): 123-133.

Abd EL- Daiem, Kh.M;Sh.A. Tantaey; R.M. Abdel Aziz and Sh.M.M. Neana(2015 b).Integrated effect of mineral nitrogen and bio fertilizer on three sweet sorghum varieties plant (Sorghum bicolor L.Moench). J. Agric. Sci., Mansoura Univ, 6 (2): 189-203.

Abou-Zeid, M.Y. and M.S.H Osman (2005). Yield and quality of sugar beet as affected by bio and mineral N-fertilization. Zagazig J. Agric. Res., 19 (2): 58-75.

Abu EL-Fotoh, H.G. ; A.A. Abd EL-Magid and R.E. Knany (2000). Effect of biofertilization on sugar beet yield, quality and optimization of the chemical fertilizers. Proc. 9th Conf. of Agron., 12 Sept. 2000, Minufiya Univ., II: 561-567.

Aly, M.E.H. (2003). Microbiological and chemical studies on the rhizosphere of sugar beet plants. Ph.D. Thesis Fac. Agric., Al-Azher Univ. 213pp.

Aly, M.H.; A. M. K. Soudi and S.H. Ashmaye (2008). The usage biofertilizer to minimize the mineral fertilizer for sweet sorghum.Egypt. J. of Appl. Sci., 23 (2B).486-499.

Aly, M.H.A.; Z.R.M اللقب. and A.M.H. Osman (2009). Effect of seed inoculation and foliar application with Azospirillum brasiliense and/or Bacillus megatherium on productivity and quality of sugar beet. Egypt. J. Appl. Sci.; 24 (2A): 56-70

Attia, A.N. ; E.M. Said ; S.E. Seadh ; S. S. El-Maghraby and M.E.M. Ibrahim (2011). Effect of sowing methods and weed control treatments on growth of sugar beet and weed characters under nitrogen fertilizer levels. J. Plant Production, Mansoura Univ., 2(6): 773-785.

Awad, N. M.M.; H.S.Gharib and S.M.I.Moustafa (2013 c). Response of sugar beet (Beta vulgaris L.) to potassium and sulphur supply in clayed soil at north delta, Egypt. Egypt. Agron. Vol.35. No.1,pp.77-99.

Awad, N. M.M.; S.F.Tawfik and S.M.I.Moustafa $\left(2013^{\mathrm{a}}\right)$.Influence of foliar spray of some micronutrients and nitrogen fertilizer on productivity of sugar beet under newly reclaimed soils. J. Agric. Res. Kafr El-Sheikh Univ.39(2):181-194.

Awad, N. M.M.; S.F.Tawfik and S.M.I.Moustafa $\left(2013^{b}\right)$. Response of two sugar beet varieties to nitrogen and magnesium fertilization at nubaria aria. J. Agric. Res. Kafr El-Sheikh Univ.39(2):195-209.

Awad, N.M. (2000). A study on the performance of two sugar beet planters one of them manufactured and developed to suit small holdings. Ph.D. Thesis, Ag. Mech. Dept., Fac. of Agric., Eng. Kafr ElSheikh, Tanta Univ. 
Awad, N.M.M.; S. F. Tawfik and S.M.I. Moustafa.(2012). Effect of plowing depth, sowing method and nitrogen fertilization on yield and quality of sugar beet. J. Agric. Res .KafrElsheikh Univ.,38(4):458-470.

Badawi, M.A. ; A.A.Kandil ; M.S. Sultan ; A.N. Attia and S.E. Seadh (2004). Effect of planting dates, biofertilization and NK combination levels on: IIYield and quality of sugar beet. The 4th Scientific Conf. of Agric. Sci., 7-9 Dec. 2004, Fac. of Agric. Assiut Univ., pp: 747- 762.

Bassal, S.A.A. ; A.A. Zohry and K.A. Douby (2001). Effect of row and hill spacings and bio-mineral $\mathrm{N}$-fertilization rates on sugar beet productivity. J. Agric. Sci. Mansoura Univ., 26(9): 5217-5226.

Cakmakci, R. ; F. Kantar and F. Sahin (2001). Effect of N2-fixing bacterial inoculation on yield of sugar beet and barley. J. of plant Nutrition and Soil Sci., 164(5): 527-531.

El-Badry, M. and A. EL-Bassel (1993). Improving sugar beet crop by inoculation with free-living nitrogen fixing bacteria. 6th Intern. Symp. on Nitrogen Fixation with non Legumes, Ismalia, Egypt.

Elkoca, E., F.Kantar and F. Sahin (2008). Influence of nitrogen fixing and phosphorus solubilizing bacteria on the nodulation, plant growth and yield of chickpea. J. plant Nut., 31:157-171.

El-Sarag, E.I. (2009). Maximizing sugar beet yield, quality and water use efficiency using some agricultural practices under North Sinai conditions Bull. of Fac. of Agric., Cairo Univ., 60(2): 155-167.

El-Sayed, S. A. M. (1998). Influence of Rhizobium and phosphate solubihizing bacteria on nutrient uptake and yield of lentil in the New Valley. Egypt J. Agric. Res., 76: 883-893.

Favilli, F. ; R. Pastorri and A. Gori (1993). Response of sugar beet to Azospirillum bacterization in field experiments. Agric. Med., 123: 281-285 (C.F. CD ROM Computer System).

Fisinin, V. I., I. A. Arkhipchenko, E.V. Popova and I. E. Solntseva (1999). Microbe fertilizers with polyfunctional properties-production with the use of fowl manure. Russ. Agric. Sci., 4:20-25.

Ghosh, D. C. and M. Mohiuddin (2000). Respone of summer sesame (Sesamum indicum) to biofertilizers and growth regulator. Agric. Sci. Digest., 20: 90-92.

Hino, S. and Wilson, P.W. (1959). Nitrogen fixation by afacultative Bacillus. J. Bacteriol. 75: 403-404.

Jackson M.L. (1973)." Soil Chemical Analysis". Prentice-Hall of India private, New Delhi.

Kandil, A.A.; M.A. Badawi ; S.A. El-Moursy and U.M.A. Abdou (2002). Effect of planting dates, nitrogen levels and biofertilization treatments on: II- Yield, yield components and quality of sugar beet (Beta vulgaris, L.). J. Agric. Sci. Mansoura Univ., 27(11): 7257-7266.
Le Doct, A. (1927). Commercial determination of sugar beet roots using the sacks le doct process. Int. Sugar J.,29: 488-492.

Maareg, M.E. and S.T. Badr (2001). Impact of three soil biofertilizers applied separately and in combinations with a nematicided on Meloidogyne incognita infecting sugar beet. Egyptian J. of Agronematology, 4(1-2): 1-9.

Maareg, M.E.; M. H. Aly; M.Y. Hussein and E.A. Tantawy (2005). Potential of Azospirillum brasiliense, Bacillus Megatherium, Glomus Mosseae and Trichoderma viride single or concomitantly for control of Root-Kotnematode, Meloidgyne Javanica infecting sugar beet Egypt. J. Agric. Res., 83(4) 1329-1341.

Ramadan, B.S.H. ; H.R. Hassan and F.A. Abdou (2003). Effect of mineral and biofertilizers on photosynthetic pigments, root quality, yield components and anatomical structure of sugar beet (Beta vulgaris L.) plants grown under reclaimed soils. J. Agric. Sci. Mansoura Univ., 28(7): 5139-5160

Steel R.G. and H.H. Torrie (1980). "Principles and Procedures of statistic". 2nd Ed. McGeaw-Hill, New York.

Seadh, S.E. (2008). Some factors affecting sugar beet productivity under newly reclaimed sandy saline soils. Proc. of the International Conf. IS - 2008 "Meeting the Challenges of Sugar Crop \& Integrated Industries in Developing Countries", IAPSIT, Al Arish, Egypt, pp: 110-115.

Shehata M.M. and S.A.El-Khamwas (2003). Effect of Two biofertilizers on growth parameters, yield characters, nitrogen components, Nucleic Acids content, minerals, oil content, protein profiles and DNA banding pattern of sunflower (Helianthus annus L. cv. Vedock) yield. Pakistan J. of Biological Sci.6 (14):1

Shewate, S.R. ; P.V. Ghodke and A.S. Patil (2008). Effect of nitrogen levels and varieties on sugar beet growth, yield and quality. Cooperative Sugar, 39(11): 29-33.

Soudi, A.M.K.; S. E. H. Omran and Kh. A. Aboushady (2008). The response of sugar beet to mineral nitrogen and phosphor fertilization partial biofertilization and some micronutrints foliar application. Egypt. J. of Appl. Sci.,23 (4B) 502516.

Sprenat, J.I. (1990). "Nitrogen fixation organisms". P.S. Chapman \& Hall, London

Sukhovitskaya, L. A. (1998). Survival retest and growth stimulating affects of Bucillus megatherium and Agrobacterium radiobacter strains. Introduced into soil. (BIBLIOGRAPHIC CITATION): Applied Biochemistry and Microbiology [Appl.-Biochem. Microbiol.]1998 vol. 34, no. 1, pp. 81-83.

Sultan, M.S. ; A.N. Attia ; A.M. Salama ; A.E. Sharief and E.H. Selim (1999). Biological and mineral fertilization of sugar beet under weed control: ISugar beet productivity. Proc. 1st Intern. Conf. on Sugar and Integrated Industries "Present \& 


\section{Sahar H. Rashed et al.}

Future", 15-18 Feb. 1999, Luxor, Egypt, I: 170181

Zhang, J.X. ; L. Qiang ; X. LiHua and G. YuZhu (2009). Effects of nitrogen fertilization on fibrous root distribution and activity in high yield sugar beet. Plant Nut. and Fertilizer Sci., 15(4): 904-909.

Zodape, S. T., (2001). Seaweeds as a biofertilizers. J. Sci. Ind. Res., 60: 378-382.

\section{رفع كفـاءة وإنتاج وجودة بنجر السكر باستخدام تلقيح البذور و الاضـافة الورقيـة بالأزوسبيريللم بـرازيلينس و الباسلس ميجاثيريوم

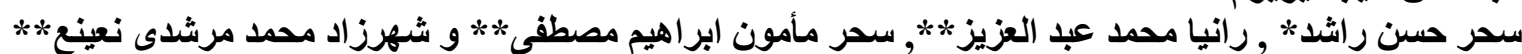

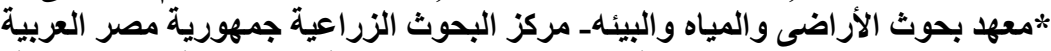

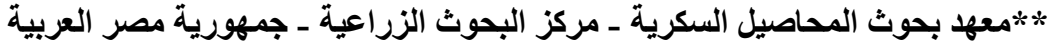

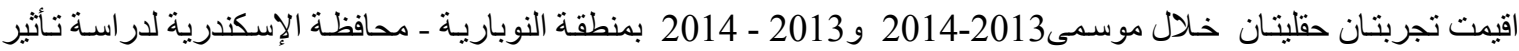

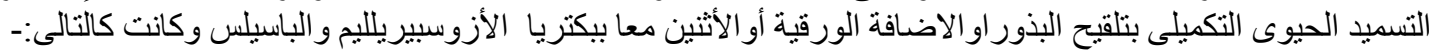

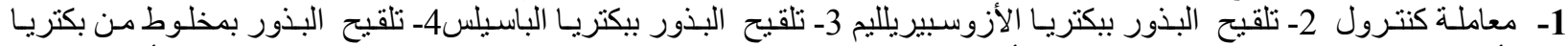

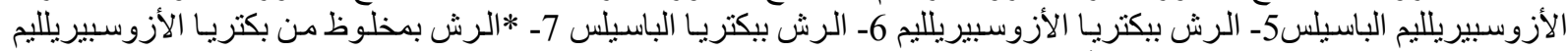

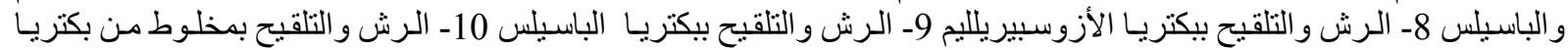

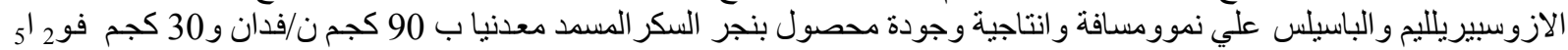
/فدان.وقد كان التصميم المستخدم هو قطاعات كاملة العشو ائية.

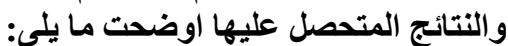

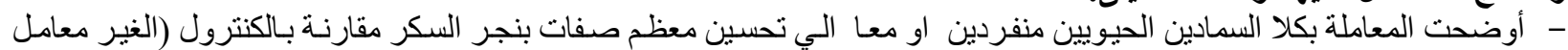

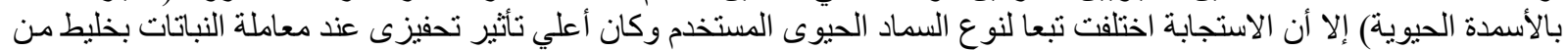

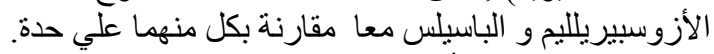

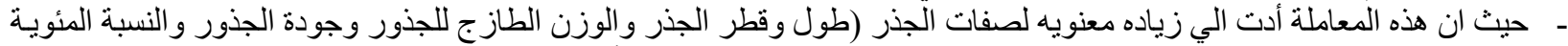

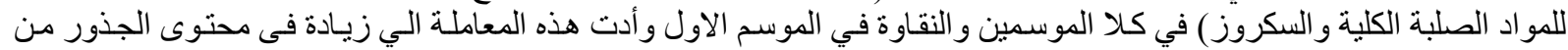

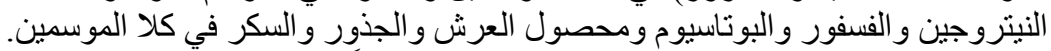

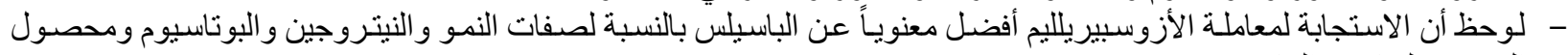

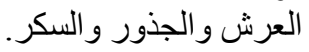

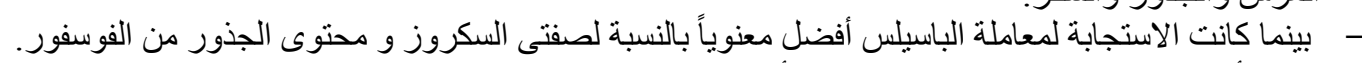

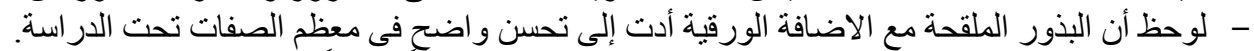

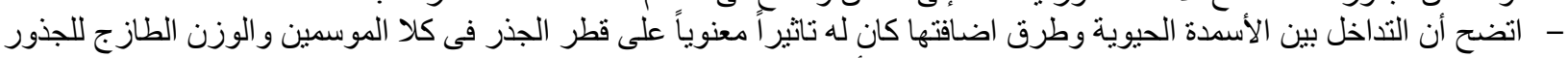

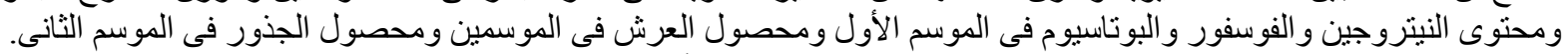

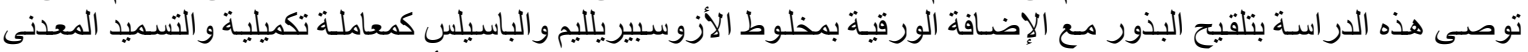

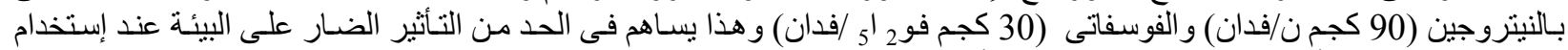

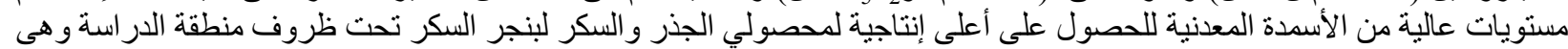
أر اضى جديدة حديثة الاستزر الاع. 